\title{
Przeszkody i wyzwania w pracy zawodowej logopedy podczas pandemii Covid-19
}

Obstacles and Challenges in the Work of a Speech Therapist
During the Covid-19 Pandemic

Słowa kluczowe: terapia logopedyczna, COVID-19, pandemia, logopeda

Keywords: speech therapy, COVID-19, pandemic, speech therapist

\section{Streszczenie}

Pandemia COVID-19 to czas, który zmienił funkcjonowanie większości zawodów. Logopedzi to jedna z grup, których praca została w szczególnym stopniu utrudniona. Podczas pracy logopeda powinien mieć widoczne usta - wymóg ten jest związany z koniecznością prezentowania pacjentom prawidłowego układu warg i języka, co jest niemożliwe z maseczką ochronną. Natomiast brak maseczki sprawia, że gwałtownie wzrasta ryzyko zarażenia. W trakcie terapii powinny być widoczne również usta pacjenta, by umożliwić logopedzie korektę nieprawidłowej artykulacji. Założeniem omawianego w tekście badania było sprawdzenie, czy logopedzi podejmowali pracę bezpośrednią podczas izolacji, a jeżeli tak, to w jaki sposób zabezpieczali się przed zagrożeniem. Pytano również o to, jakie zmiany zauważyli u siebie (np. spadek motywacji, złe samopoczucie), a jakie u swoich pacjentów (postępy w terapii, kondycja psychiczna, motywacja do ćwiczeń). Zastanawiano się również nad tym, czy podejmowali się pracy online i jak ją oceniali, pamiętając, że elementem terapii logopedycznej jest również manualne wywoływanie głosek (np. za pomocą szpatułki bądź wibratora logopedycznego), masaż, ale też budowanie relacji z pacjentem, na przykład podczas gier i zabaw logopedycznych. Zawód logopedy charakteryzuje się bliską relacją z uczestnikiem terapii, zarówno dzieckiem, jak i z dorosłym, co może jednak zwiększać ryzyko zarażenia się i wpływać na komfort pracy.

\footnotetext{
* Państwowa Uczelnia im. Stefana Batorego, Instytut Nauk Społecznych, ul. Batorego 64C, 96-100 Skierniewice, e-mail: anna.karowicz@gmail.com, ORCID: https://orcid.org/0000-0001-8988-0910.
} 


\section{Abstract}

The global COVID-19 pandemic has changed the functioning of most professions. Speech therapists are one of the groups whose work has been significantly hindered. At work, the speech therapist is ought to have his mouth visible to demonstrate the correct placement of the lips and tongue to the patients - which is impossible with a protective mask on. The lack of a mask, in turn, increases the risk of infection dramatically. The patient's mouth should also be visible to allow the therapist to correct any articulation errors. In the research presented in the text, the author decided to check whether speech therapists have undertaken any direct work with their patients during confinement, and if so, what protective measures they have implemented. During the interview speech therapists were also asked if they have noticed any changes in their frame of mind (e.g. decreased motivation, malaise) and, if they had already returned to work, if they have observed any changes in their patients behaviour (progress in therapy, mental condition, motivation). The aim of the research was also giving an answer to the question, if they had undertaken online work and how they have assessed it, bearing in mind that tactile therapy (e.g. using a spatula or speech therapy vibration tools), therapeutic speech massage and forming a relationship with the patient, e.g. during speech therapy games, are essential elements of speech therapy. The profession of a speech therapist is characterized by a close relationship with the patient, both children and adults, which, during the pandemic, may increase the risk of infection and might affect the overall comfort of work.

\section{Wprowadzenie - ogólne uwarunkowania wykonywania zawodu logopedy w okresie pandemii COVID-19}

Wybuch pandemii COVID-19 był momentem, w którym cały świat zmienił sposób funkcjonowania. Rozprzestrzenienie się wirusa SARS-CoV-2 nie stanowiło jedynie wyzwania o charakterze medycznym, wymusiło także na większości instytucji i środowisk zawodowych konieczność dostosowania się do nowej rzeczywistości. Z wdrażaniem zmian czy procesów dostosowawczych musiały się zmierzyć praktycznie wszystkie środowiska zawodowe, a w szczególnym stopniu te, których zadania są realizowane w bezpośredniej interakcji z drugim człowiekiem. Adaptacja do nowych warunków była nierzadko tak dużym wyzwaniem, że wiele osób zostało zmuszonych do zamknięcia swoich prywatnych działalności. Do zawodów, dla których pandemia COVID-19 stanowiła tak duże wyzwanie, można zaliczyć między innymi zawód logopedy.

W powszechnej świadomości logopeda postrzegany jest jako osoba zajmująca się wadami wymowy, ćwiczeniami aparatu artykulacyjnego przed lustrem czy problemami z wyraźnym mówieniem. Stereotypowe wyobrażenie o roli tego specjalisty rzadko zakłada szersze kompetencje wpisujące się w ten zawód. Mając na uwadze tę prawidłowość, warto zarysować kontekst wykonywania zawodu logopedy. 
Logopedyczna opieka nad pacjentem może się rozpocząć tuż po narodzinach, na długo przed wykształceniem mowy. Neurologopeda ma wówczas za zadanie sprawdzanie odruchów niemowlęcych, kontrolowanie budowy narządów artykulacyjnych, a także doradzanie w przypadku wystąpienia problemów z karmieniem. Częste męczenie się niemowlęcia podczas karmienia, prężenie, ulewanie, odczuwanie bólu przez matkę to pierwsze sygnały mogące świadczyć o problemach logopedycznych, na przykład o skróconym wędzidełku językowym [Kaczorowska-Bray, Zielińska-Burek, 2012, s. 55-94].

Już na tym najwcześniejszym etapie pracy logopeda potrzebuje bliskiego kontaktu z pacjentem i dotykania wnętrza jego jamy ustnej. Stawianie diagnozy bez fizycznej współobecności terapeuty i pacjenta nie jest możliwe. Każdy uczestnik terapii, bez względu na wiek, musi być oceniony pod kątem budowy i sprawności narządów artykulacyjnych: zgryzu, podniebienia i wędzidełka językowego, którego skrócenie często nie jest wykrywane na wczesnym etapie rozwoju dziecka. Nieprawidłowa budowa wędzidełka językowego odbija się nie tylko na artykulacji, ale również na problemach z żuciem, przełykaniem, pozycją spoczynkową języka, a w konsekwencji nawet na nieprawidłowej budowie twarzoczaszki i wadach zgryzu. Podczas diagnozy istotne jest więc nie tylko słuchanie, jak dziecko mówi, ale również kontrola tego, jak oddycha, gryzie, żuje i przełyka [Sambor, 2015, s. 149-188]. Aby dziecko rozwijało się prawidłowo, powinno poznawać rzeczywistość za pomocą wszystkich zmysłów i rozwijać jednocześnie wiele innych kompetencji [Cieszyńska-Rożek, Korendo, 2015, s. 63]. Proces diagnozy to czas, w którym należy poznać przypadek, poszukać przyczyn wad wymowy i nieustannie obserwować pracę narządów artykulacyjnych. Wdrażanie coraz doskonalszych rozwiązań technicznych pozwalających na zdalną konsultację nie jest więc w tych przypadkach optymalnym rozwiązaniem. Proces diagnozy logopedycznej opiera się bowiem na bodźcach sensorycznych zbyt subtelnych, by nawet najbardziej doświadczony specjalista mógł zdać się na wykorzystanie kamery i mikrofonu podłączanych do komputera.

Logopedia to nauka o biologicznych uwarunkowaniach języka i zachowań językowych, w przypadku których istotne są kompetencje komunikacyjne, ale również językowe, poznawcze i realizacyjne [Grabias, 2010, s. 9-34]. Podstawą rolą logopedii jest umożliwianie komunikacji, niezwykle istotna jest tu więc zdolność rozumienia, percepcji, budowania słownika, kontaktu wzrokowego, utrzymywania wspólnego pola uwagi. Podczas diagnozy logopedycznej sprawdzane są wszelkie umiejętności komunikacyjne dziecka - rozumienie, reakcja na imię i polecenia, słownictwo bierne i czynne. Te umiejętności można skontrolować, będąc zabezpieczonym maską, a także sprawdzić zdalnie na podstawie wywiadu z rodzicem, filmików czy rozmowy $z$ dzieckiem przez internet. Praca zdalna nie daje jednak możliwości pełnej diagnozy logopedycznej. W niniejszym artykule skupiono się na aspektach terapii logopedycznej, która wymaga bezpośredniego kontaktu, i na procesach realizacyjnych. Logopedia jest dziedziną interdyscyplinarną, zwracającą uwagę nie tylko na artykulację, ale 
i na zagadnienia wynikające na przykład z wad zgryzu, problemów laryngologicznych czy fizjoterapeutycznych [Pluta-Wojciechowska, 2020, s. 141-155]. Poza terapią wad wymowy logopeda przeprowadza również terapię dotyczącą zaburzeń pozycji spoczynkowej języka, przełykania czy żucia. Terapia ta wymaga bezpośredniej ingerencji w aparacie artykulacyjnym, poprzez odpowiednie ustawianie języka, masaż jamy ustnej, wkładanie pokarmów w prawidłowy sposób, a także używanie narzędzi terapeutycznych, takich jak szpatułki, gryzaki logopedyczne, tubki żuchwowe, wibratory logopedyczne itp. Wszystko to wymaga bliskiego kontaktu z pacjentem i jego twarzą, która nie może być zasłonięta maską. Używając narzędzi, terapeuta musi znajdować się naprzeciwko pacjenta, co naraża na oplucie, nawet przez samą pracę wibratora logopedycznego, bez złej woli pacjenta. Pracując nad dykcją, logopeda koryguje pracę artykulatorów. Wykonywanie tego zadania obejmuje dotykanie języka lub podniebienia pacjenta w celu manualnego wywołania głoski lub uwrażliwienia miejsca, którego powinien dotykać język. W większości przypadków twarz logopedy powinna być widoczna. Praca z dziećmi łączy się również z przytulaniem, trzymaniem ich na kolanach, masażami twarzy lub jamy ustnej i nieustanną bliskością. Wynika $z$ tego, że logopeda jest szczególnie narażony na zarażenie wirusem wywołującym COVID-19, więc by chronić zdrowie własne i pacjentów, jest zmuszony do zachowania szczególnych środków ostrożności.

Mając na uwadze zarówno przesłanki wynikające ze specyfiki pracy logopedy, jak i szczególny charakter narażenia tych specjalistów na choroby wywoływane przez wirusy przenoszone drogą kropelkową, należy zauważyć, że praca logopedy w okresie pandemii COVID-19 jest jednym z bardziej interesujących poznawczo zagadnień. Specjaliści ci w następstwie zaistniałych okoliczności zostali bowiem skonfrontowani z bardzo trudnym wyzwaniem. $Z$ jednej strony wymogi rzetelnego wykonywania ich pracy nakazują fizyczną współobecność terapeuty i pacjenta, z drugiej zaś względy bezpieczeństwa sugerują poszukiwanie wszelkich rozwiązań minimalizujących ryzyko transmisji wirusa pomiędzy logopedą i jego pacjentem. Ta immanentnie wpisana w warunki pracy logopedy sprzeczność prowadzi do założenia, że realia pandemii mogą powodować narastanie wśród logopedów różnego rodzaju napięć i obaw, a także stanowi przesłankę do wypracowywania nowych koncepcji organizowania pracy terapeutycznej.

\section{Metodologia i metodyka badań}

Problematyka badawcza objęła kilka wybranych aspektów funkcjonowania logopedów podczas pandemii wirusa COVID-19. Pierwszym z nich było ich samopoczucie w kontekście wystąpienia nowych uwarunkowań wykonywania zawodu. Drugi aspekt odnosił się do wdrożonych ogólnych sposobów organizowania pracy terapeutycznej, trzeci zaś dotyczył szczegółowych sposobów zabezpieczania się przed 
wirusem i narzędzi stosowanych w tym celu. Badanie zostało zrealizowane wśród logopedów (w tym neurologopedów) pracujących zarówno w przedszkolach, szkołach, szpitalach, jak i w prywatnych gabinetach. Ze względu na specyfikę zawodu i bliski kontakt z pacjentem celem badań było sprawdzenie, jak logopedzi zachowywali się podczas pierwszego etapu pandemii (od marca do lipca 2020 roku) pod kątem środków ochrony, sposobów pracy, kontaktu z pacjentem.

Przed podjęciem badań przyjęto hipotezę badawczą zakładającą, że logopedzi niewystarczająco zabezpieczają się przed możliwością zarażenia. Do jej sformułowania sprowokowały autorkę przekazy publikowane na portalach społecznościowych, w tym zdjęcia przedstawiające logopedów jedynie w przyłbicach lub tzw. maseczkach $\mathrm{z}$ okienkiem. Według badań medycznych przyłbice nie zapewniają należytej ochrony przed transmisją wirusa, gdyż jest on przenoszony drogą kropelkową i swobodnie przedostaje się pod lub nad ekranem przyłbicy [Landsverk, 2020]. Wiele zdjęć pokazywało również specjalistów bez jakichkolwiek zabezpieczeń. Rozpowszechnione w serwisach internetowych przekazy nie powinny stanowić głównej podstawy do orzekania o środkach ostrożności wdrażanych przez tę grupę zawodową oraz - w konsekwencji - do oceniania stanu jej świadomości czy postaw wobec zagrożenia epidemicznego. Uchwycony obraz stanowił więc dla autorki przesłankę do realizacji badania, którego zadaniem było przedstawienie bardziej rzetelnego i pełniejszego obrazu zjawiska.

\section{Charakterystyka badanej grupy}

Badania przeprowadzono w lipcu 2020 roku wśród 340 logopedów. Zastosowana została technika ankiety internetowej (computer-assisted web interview), dzięki czemu wypełnili ją badani z całej Polski - z województw: mazowieckiego (70 osób - 20,6\%), małopolskiego (38 osób - 11\%), śląskiego (32 osoby - 9,4\%), dolnośląskiego (30 osób - 8,8\%), pomorskiego ( 29 osób - 8,5\%), łódzkiego ( 25 osób - 7,3\%), wielkopolskiego (22 osoby - 6,4\%), kujawsko-pomorskiego (18 osób - 5,3\%), lubelskiego (15 osób - 4,4\%), podkarpackiego (14 osób - 4,1\%), zachodniopomorskiego (11 osób - 3,2\%) i warmińsko-mazurskiego (11 osób - 3,2\%), podlaskiego (8 osób - 2,3\%), opolskiego (6 osób - 1,8\%), lubuskiego (5 osób - 1,4\%) oraz świętokrzyskiego (4 osoby - 1,1\%). Internet (a przede wszystkim dostępne w nim media społecznościowe, fora internetowe i czaty) pozwala na dotarcie do szerokiej grupy odbiorców o pożądanych przez nas cechach [Kozinets, 2012, s. 20-30]. W tym przypadku pomocą okazał się głównie portal Facebook i tematyczne grupy zrzeszające logopedów i neurologopedów.

Znaczną większość ankietowanych stanowiły kobiety (w badaniu wziął udział tylko jeden mężczyzna, co stanowi mniej niż $1 \%$ wszystkich ankietowanych). Badani pochodzili głównie z miast - 147 osób z miasta do 200 tys. mieszkańców (46\%), 138 osób z miasta powyżej 200 tys. mieszkańców (40,6\%), a 51 osób ze wsi (13,4\%). 
W przedszkolach lub szkołach pracowało 197 osób (57\% wszystkich ankietowanych) - 119 osób w przedszkolach (35\%), 78 osób w szkołach (22\%); 107 osób w prywatnych gabinetach (31,5\%), 58 osób w poradniach psychologiczno-pedagogicznych (17\%), a 14 osób w szpitalach (4\%).

Ankietowani byli w wieku od 23 do 60 lat. Średnia wieku wynosiła 36 lat.

Wykorzystanym narzędziem badawczym był kwestionariusz elektronicznej ankiety, składający się zarówno z pytań zamkniętych (jedno- i wielokrotnego wyboru), jak i pytań otwartych. Łącznie logopedzi odpowiadali na 23 pytania, a dodatkowo otrzymali sposobność przedstawienie własnych spostrzeżeń pod koniec ankiety ${ }^{1}$. Pytania dotyczyły zarówno opinii logopedów o pracy w warunkach pandemii, jak i deklaracji dotyczących ich zachowań oraz rozwiązań stosowanych w celu poprawy bezpieczeństwa. W przypadku pytań o zmiany, które zaszły w okresie pandemii, uwzględniono zarówno samo dostrzeżenie zmiany, jak i waloryzowanie dostrzeganych zmian jako pozytywnych bądź negatywnych. Oceny te były dokonywane w zależności od kontekstu: dla samego logopedy lub - według jego oceny - dla efektów pracy terapeutycznej.

\section{Omówienie wyników badania wraz z zarysowaniem szerszego kontekstu uchwyconych zjawisk}

Uwarunkowania towarzyszące pandemii COVID-19 wpłynęły na kondycję psychiczną większości środowisk społecznych, lecz - co należy podkreślić - niektóre grupy zawodowe zostały poddane szczególnej presji wynikającej z narażenia na infekcję i z konieczności stosowania środków zabezpieczających przed nią. Problematyka stresu i przemęczenia wśród lekarzy, pielęgniarek i ratowników medycznych została obszernie omówiona w książce Pandemia autorstwa Pawła Kapusty [2020, s. 10-35]. Co ciekawe, ze względu na zwiększenie poziomu stresu w populacji do logopedów, ortodontów czy fizjoterapeutów zwraca się też więcej pacjentów z bruksizmem [Koronawirus ma zwiazek z przypadkami bruksizmu?, 2020], co jest potwierdzeniem, że pandemia wpływa negatywnie na ogólne funkcjonowanie społeczeństwa.

\section{Wpływ pandemii na komfort psychiczny}

Wśród badanych logopedów 263 osoby (77,3\%) zadeklarowały, że pandemia wpłynęła negatywnie na ich komfort psychiczny, 57 osób (16,8\%) nie dostrzegało wpływu pandemii na własne samopoczucie, a tylko 20 osób (5,9\%) zauważyło poprawę swojej kondycji psychicznej. W świetle omawianych wyników badania pandemia miała również negatywny wpływ na pracę logopedów. Możliwość wykonywania

1 Ankieta dostępna pod linkiem: https://docs.google.com/forms/d/e/1FAIpQLSdzizrKSKzyQSOAw ro24OvjxR0SM46VVhtktF2vG_A1PK8p1Q/viewform?usp=sf_link (dostęp: 2.11.2020). 
pracy w nowych warunkach została negatywnie oceniona przez $80,5 \%$ respondentów (274 osoby), podczas gdy 10,5\% (36 osób) nie dostrzegło takiego wpływu, a 9\% (30 osób) uznało pandemię za pozytywny czynnik oddziałujący na ich życie zawodowe.

\section{Forma pracy}

$\mathrm{Z}$ powodu pandemii $\mathrm{w}$ wielu zawodach alternatywą dla pracy stacjonarnej stała się praca online. Wśród badanych logopedów 291 osób (85,5\%) również zdecydowało się na tę formę pracy, a 49 osób (14,5\%) nie pracowało online w żadnym okresie. Jedynie 6 ankietowanych $(1,7 \%)$ pracowało stacjonarnie przez cały czas trwania pandemii i wprowadzania obostrzeń. Kolejne 72 osoby $(21,1 \%)$ zdecydowały się na mieszaną formę pracy - i pracowały zarówno online, jak i stacjonarnie, 149 osób $(43,8 \%)$ wybrało jedynie formę zdalną, 18 osób (5,2\%) nie pracowało wcale, a 67 osób (19,7\%) początkowo nie pracowało, ale już powróciło do pracy stacjonarnej. Przed pandemią $\mathrm{w}$ formie zdalnej pracowało jedynie 14 osób $(4,1 \%)$. Wynika z tego, że 326 badanych logopedów $(95,9 \%)$ wcześniej nie próbowało korzystać z technik terapii na odległość. Pandemia skłoniła więc tych specjalistów do zmiany sposobu pracy na zdalną, czyli w pełni zabezpieczającą przed transmisją wirusa SARS-CoV-2. Badania zostały przeprowadzone po pierwszej fali pandemii, czyli w lipcu 2020 roku. W związku z tym, że ograniczenia trwały już od marca tego roku, kiedy wirus dotarł do Polski, w lipcu pytano ankietowanych, czy zdecydowali się wrócić do bezpośredniej pracy z pacjentem. W chwili wypełniania kwestionariusza ankiety 39 respondentów $(11,5 \%)$ nie wróciło jeszcze do tej formy pracy i nie planowało tego w najbliższym czasie. W kwietniu wróciło 9 osób (2,7\%), w maju i czerwcu po 106 osób (po 31,3\%), w lipcu 30 osób (8,8\%), a 47 osób (13,9\%) planowało wrócić w najbliższych miesiącach.

Należy podkreślić, że powrót do pracy nie zawsze był decyzją logopedy. O ile 126 badanych (37\%) samodzielnie podjęło decyzję o powrocie do pracy bezpośredniej, to w przypadku 139 ankietowanych (41\%) zadecydował o tym ich pracodawca, a oni nie mieli nic przeciwko powrotowi do prowadzenia zajęć terapeutycznych. Pozostałych 61 badanych (18\%) wróciło do pracy za sprawą decyzji pracodawcy, chociaż samodzielnie jeszcze nie podjęliby takiej decyzji z uwagi na ryzyko zarażenia się wirusem. Logopedzi zapytani o to, czy podczas pracy bezpośredniej z pacjentem czują się bezpiecznie, w ponad połowie ankiet udzielili odpowiedzi twierdzącej (190 osób - 56\%). Znaczna część badanych (150 osób - 44\%) czuła się jednak zagrożona przez bliski kontakt $\mathrm{z}$ pacjentem i duże ryzyko zarażenia.

Nauka mowy w głównej mierze opiera się na mechanizmie naśladownictwa. Mając to na uwadze, respondentów zapytano, czy ich zdaniem usta logopedy muszą być widoczne podczas jego pracy. Niemal powszechne było przekonanie (335 osób - 98,5\% odpowiedzi), że widoczność twarzy jest warunkiem koniecznym, by terapia przyniosła oczekiwane efekty. Jedynie 5 osób $(1,5 \%)$ nie miało zdania na ten temat. Badani w większości (214 osób - 62,9\%) twierdzili, że logopedzi nie mają możliwości 
wykonywania w pełni bezpiecznej pracy podczas pandemii. Blisko jedna trzecia (112 osób - 32,9\%) sądziła, że jest taka możliwość, a 14 ankietowanych $(4,1 \%)$ nie odpowiedziało rozstrzygająco na to pytanie.

\section{Postrzegane przyczyny ryzyka pracy w kontakcie bezpośrednim}

W kwestionariuszu ankiety respondenci otrzymali możliwość uzasadnienia udzielonej odpowiedzi. Ponad jedna trzecia badanych logopedów (118 osób - 34,7\%) jako argument na poparcie opinii o braku możliwości bezpiecznego wykonywania pracy podawała zbyt bliski kontakt $\mathrm{z}$ pacjentem, jego twarzą, a w szczególności jamą ustną. Zwracali oni uwagę na konieczność przeprowadzania masażu logopedycznego wewnątrz jamy ustnej, dotykania twarzy pacjenta, kontrolowania ułożenia języka, manualnego wywoływania głosek, na przykład szpatułką bądź wibratorem logopedycznym. Ponadto 34 ankietowanych (10\%) przypomniało, że dzieci nie mają obowiązku noszenia maseczek, a w ich przypadku wirus ma łatwiejszą drogę do przeniesienia się i częściej występuje bezobjawowo, więc można przeoczyć zakażenie. Badani zauważali również (41 osób - 12\%) nieodpowiedzialne zachowanie rodziców, którzy przyprowadzają do terapeuty chore dzieci, nie dbają o ich higienę albo sami nie noszą masek w gabinetach. Można bowiem wśród rodziców dostrzec zachowania wskazujące na niską obawę przed ryzykiem zarażenia się wirusem i jego poważnymi następstwami. Osoby, które uważały, że logopedzi mają możliwość bezpiecznej bezpośredniej pracy, argumentowały to „zachowaniem odpowiednich środków ostrożności" (88 osób - $26 \%$ ), choć wypowiedzi te przeważnie nie zostały rozwinięte o konkretne wytyczne. Wśród dostępnych środków ochronnych wskazywane były przyłbica i rękawiczki (41 osób - 12\%). Natomiast nikt spośród badanych w tym pytaniu nie wskazał maseczki jako odpowiedniego zabezpieczenia.

Poziom wiedzy logopedów na temat bezpieczeństwa podczas pandemii należy uznać za ograniczony. W świetle badań dotyczących transmisji wirusa skuteczną obronę przed nim stanowią maski z wysokim filtrem (ffp2 lub ffp3) w połączeniu z przyłbicą lub okularami ochronnymi, gdyż wirus może wnikać do organizmu nie tylko poprzez drogi oddechowe, lecz również przez oczy [Emanuel i wsp., 2020]. Przyłbica bez równoczesnego zastosowania maski nie chroni należycie przed infekcją [Verma, Dhanak, Frankenfield, 2020]. Maski z wysokim filtrem były używane jedynie przez 3 spośród 340 badanych, co daje mniej niż 1\% ankietowanych. Jedynie 44 osoby (13\%) zdecydowały się na klasyczne maseczki wykonane z bawełny, a 17 osób (5\%) na „maseczki z okienkiem”, czyli maski z wszytym pośrodku kawałkiem plastiku, w taki sposób, aby widoczne pozostały usta użytkownika maski. Tak więc łącznie z ochrony za pomocą maseczki korzystało jedynie 65 badanych (19\%). Większość osób (228 - 67\%) używała przyłbic, które w świetle fachowych badań nie dają wystarczającej ochrony przed przenoszeniem się wirusa. Zastanawiające było również to, co dla logopedów było najtrudniejsze w pracy podczas pandemii. Jak się okazuje, najtrudniejsze okazały się: ograniczony kontakt z pacjentem (231 osób - 68\%), 
brak możliwości korzystania z niektórych pomocy terapeutycznych i zabawek (184 osoby - 54\%) i konieczność pracy online (167 osób - 49\%). Znaczna liczba ankietowanych (136 osób - 40\%) jako trudność wymieniała stres związany z pandemią.

\section{Stosunek badanych do pracy zdalnej}

Z uwagi na fakt, że wielu logopedów nie miało wcześniejszych doświadczeń związanych z pracą zdalną (dla przypomnienia - przed pandemią online pracowało jedynie 14 badanych - 4,1\%), sprawdzono, czy mają oni zamiar kontynuować ten rodzaj prowadzenia terapii również po zakończeniu pandemii i towarzyszących jej zaleceń czy obostrzeń. Jedynie 44 osoby $(12,9 \%)$ deklarowały zamiar dalszego korzystania z technik prowadzenia zajęć na odległość, 117 osób $(34,4 \%)$ nie podjęło decyzji w tej kwestii, a ponad połowa ankietowanych (179 osób - 52,6\%) przyznała, że nie będzie pracować zdalnie, jeżeli nie będzie miała takiego obowiązku. Odpowiadając na pytanie o wydajność terapii online dla poszczególnych grup wiekowych, 299 ankietowanych (88\%) przyznało, że ten rodzaj terapii nie jest w stanie zastąpić bezpośredniej pracy z pacjentem. Nieco ponad jedna piąta osób (71 - 21\%) odpowiedziała, że terapia może być wydajna dla dzieci powyżej 9. roku życia i dla dorosłych, 51 osób (15\%) uważało, że sprawdzi się w przypadku pacjentów w wieku 6-9 lat, ale już tylko 14 logopedów (4\%) uznało ją za zasadną u dzieci w wieku 3-6 lat, a mniej niż $1 \%$ ankietowanych (1 osoba), że u dzieci do 3 lat. Wynika z tego, że im pacjent jest starszy, tym zdalna współpraca ma większą szansę na przyniesienie efektów.

W celu rozwinięcia i pogłębienia niniejszych rozważań warto przywołać inne badanie poruszające kwestię tego, czy terapia online ma szansę się sprawdzić. W prowadzonych badaniach Joanna Jatkowska [2020, s. 73-84], przewidując możliwe do osiągnięcia efekty terapii prowadzonej $\mathrm{w}$ formie zdalnej, uwzględniła również przyczyny jej podjęcia. Stwierdziła, że zajęcia prowadzone przez internet sprawdzają się najlepiej u dzieci z dyslalią jednoraką (dla 43\% terapia była bardzo skuteczna, a dla $57 \%$ średnio skuteczna), mniej z dyslalią wieloraką (dla 18\% bardzo skuteczna, dla 53\% średnio skuteczna, chociaż aż 13\% zrezygnowało w trakcie trwania badań). Najmniej skuteczne zajęcia dotyczyły dzieci z bardziej złożonymi problemami, na przykład z dysglosją audiogenną, oligofazją, dyslalią całkowitą - w ich przypadku zajęcia zdalne zupełnie nie zdawały egzaminu, nie przynosiły oczekiwanych efektów.

Wyniki badania przeprowadzonego przez autorkę niniejszego tekstu potwierdzają, że logopedzi negują celowość pracy online w przypadku większości zaburzeń, przede wszystkim autyzmu (258 osób - 76\%), zaburzeń przełykania (235 osób - 69\%), opóźnionego rozwoju mowy (211 osób - 62\%), mutyzmu wybiórczego (211 osób - 62\%) czy nieprawidłowej pozycji spoczynkowej języka (235 osób - 69\%), wad wymowy (150 osób - 44\%), jąkania (126 osób - 37\%), afazji (167 osób - 49\%). Blisko dwie trzecie ankietowanych (221 osób - 65\%) twierdziło, że zdalnie nie da się prawidłowo ocenić budowy i sprawności narządów artykulacyjnych, w tym wędzidełka podjęzykowego. Szeroki zakres kompetencji logopedy (od wywiadu logopedycznego, przez 
kontrolę budowy narządów artykulacyjnych, masaż logopedyczny, aż do terapii wad wymowy i nieprawidłowego przełykania) sprawia, że terapia online w większości przypadków jest trudna i mało wydajna lub wręcz niemożliwa.

Terapia online nie jest wydajna w przypadku:

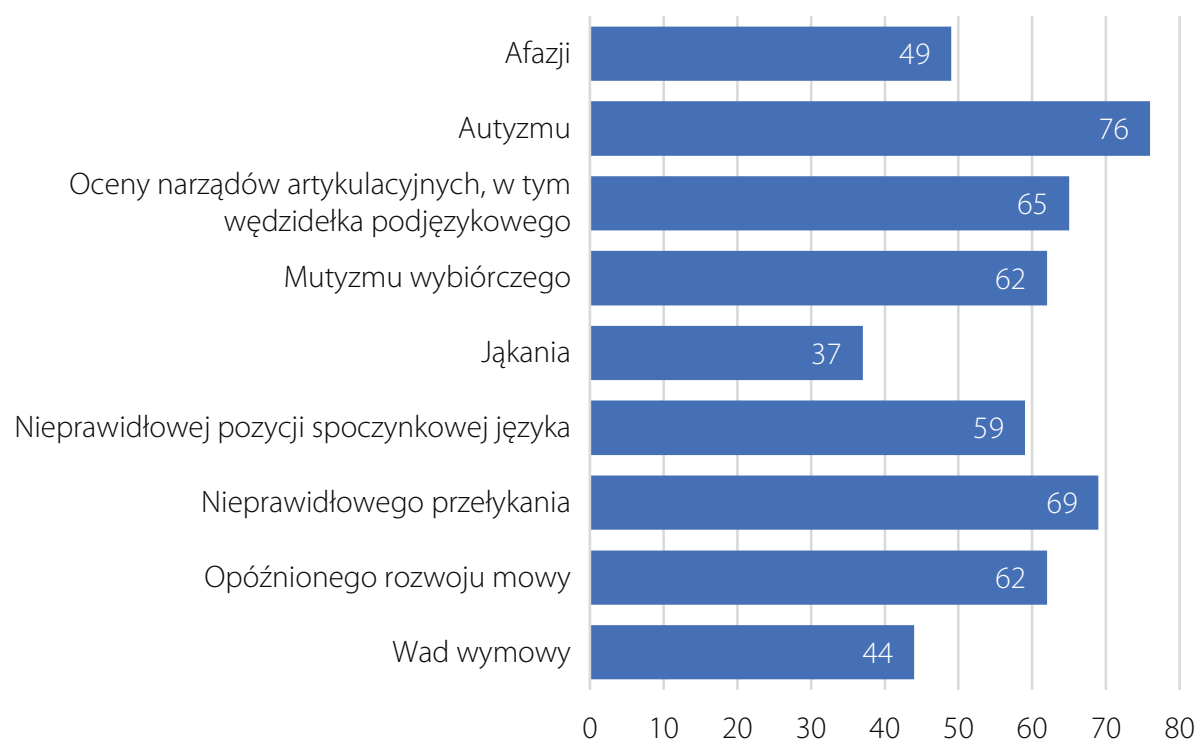

Rysunek 1. Wydajność terapii online z perspektywy logopedów

Źródło: opracowanie własne.

Zaprezentowane dotychczas wyniki warto również zestawić z kolejnymi badaniami realizowanymi wśród logopedów w okresie pandemii. Należy jednak zastrzec, że krótki okres, jaki upłynął od jej wybuchu, w połączeniu z wąskim obszarem problemowym, sprawia, że analizy te wciąż jeszcze są nieliczne, a często też realizowane na niewielkich próbach badawczych, co - jak należy zakładać - podyktowane jest w głównej mierze chęcią upowszechnienia pierwszych zarysów nowych zjawisk czy dynamicznie kształtujących się postaw. W maju 2020 roku w Indiach zbadano 84 logopedów pracujących za pomocą konsultacji online. Nieco ponad połowa z nich (52\%) stwierdziła, że terapia online jest bardziej stresująca niż tradycyjna forma wykonywania pracy. Zdaniem 31\% nie była ona stresująca, lecz pozostali nie rozstrzygnęli jednoznacznie tej kwestii. Blisko połowa logopedów biorących udział w tym badaniu (49\%) chciałaby pracować zdalnie po zakończeniu pandemii, $34 \%$ jedynie czasami, a 17\% preferowało wyłącznie terapię bezpośrednią. Co warte podkreślenia, $35,5 \%$ oceniało terapię online jako równoważną z bezpośrednią, lecz już 33,4\% wolało jej formę bezpośrednią, a 31,7\% nie miało w tej kwestii zdania [Aggarwal, Patel, Ravi, 2020, s. 1-8]. 
W Chinach podczas pandemii (na przełomie lutego i marca 2020 roku) zbadano 135 logopedów. Jedynie 35\% respondentów wykonywało telepraktykę, a $65 \%$ zupełnie zrezygnowało z pracy na czas pandemii. Wśród osób korzystających z terapii online $51 \%$ uznało, że jest ona mniej skuteczna niż bezpośrednia, 26\% stwierdziło, że jest porównywalna, a 13\% nie podjęło się rozstrzygnięcia tej kwestii. Ci logopedzi, którzy nie zdecydowali się na pracę zdalną, argumentowali to głównie brakiem możliwości uzyskania rezultatów z pacjentami (83\%), ale również brakiem prawidłowego kontaktu (52,2\%). Ponadto wskazywano bariery technologiczne (50\%) i znikomą skuteczność (40,9\%), a także brak chęci po stronie pacjentów lub ich rodziców (25\%) [Fong, Fung Tsai, Yan Yiu, 2021, s. 30-38].

Zarówno badanie autorki niniejszego tekstu, jak i badania przeprowadzone w Chinach czy Indiach wskazują, że terapia online ma liczne ograniczenia i w wielu przypadkach nie może zastąpić pracy bezpośredniej. Wracając do wyników badania stanowiącego punkt wyjścia dla niniejszych rozważań, należy podkreślić, że większość pracujących w Polsce logopedów (302 osoby - 88,8\%) zauważyła, że ekran komputera nie pozwala na dokładne obejrzenie narządów artykulacyjnych pacjenta. Podczas tej czynności niejednokrotnie trzeba na przykład podnieść język pacjenta, przytrzymać mu żuchwę, palpacyjnie ocenić siłę i sprawność narządów artykulacyjnych. Większość badanych (292 osoby - 85,8\%) zwróciła uwagę na utrudniony kontakt z pacjentem i ograniczoną możliwość budowania z nim relacji. Logopedzi byli również w znacznym stopniu zgodni ( 288 osób - 84,7\%) co do niewykonalności masażu logopedycznego i braku zaangażowania najmłodszych pacjentów w zabawę z uwagi na niemożliwość wspólnego grania w gry czy używania pomocy terapeutycznych, takich jak na przykład dmuchajka logopedyczna (260 osób - 76,4\%).

Niechęć wobec pracy online podyktowana była również występowaniem problemów technicznych podczas zajęć, takich jak zacinanie się obrazu, zrywanie połączenia (252 osoby - 74,1\%) i utrudnione ilustrowanie prawidłowego ułożenia narządów artykulacyjnych podczas ćwiczeń i wymowy konkretnych głosek (233 osoby - 68,5\%). Ankietowani zauważali przy tym, że zdalne prowadzenie zajęć nie pozwala na manualne wywoływanie głosek za pomocą szpatułek, wibratora logopedycznego czy zabezpieczonych rękawiczką palców (238 osób - 70\%). Zdalne zajęcia wpływają również na problemy z koncentracją u pacjentów i monotonię pracy (216 osób - 63,5\%), a także utrudniają motywowanie pacjenta do ćwiczeń. W tym miejscu warto też przywołać badania przeprowadzone w poradniach logopedycznych w Czechach na przełomie 2018 i 2019 roku. Wskazały one, że 50 z 69 uczestniczących w nich logopedów znało terapię online i używało jej, co wskazuje, że dla Czechów konieczność zdalnej pracy logopedycznej, wymuszona przez pandemię, nie była tak dużą zmianą jak w Polsce. Mając na uwadze ten fakt, warto mocno zaakcentować, że czescy logopedzi uważają terapię online za ostateczność (26\%), 16\% terapeutów w tym kraju nie stosuje zajęć online, $15 \%$ ceni taką terapię w lżejszych przypadkach, $13 \%$ uważa ją jedynie za uzupełnienie stacjonarnych zajęć, a 12\% całkiem odrzuca 
tę metodę [Vecerkova, 2020, s. 50-55]. Tak więc Czesi również bardziej cenią pracę bezpośrednią z pacjentem i dostrzegają ograniczenia zdalnej terapii, choć mieli dłuższy czas na zaznajomienie się $\mathrm{z}$ tą formą pracy $\mathrm{z}$ pacjentem.

\section{Wady terapii logopedycznej online}

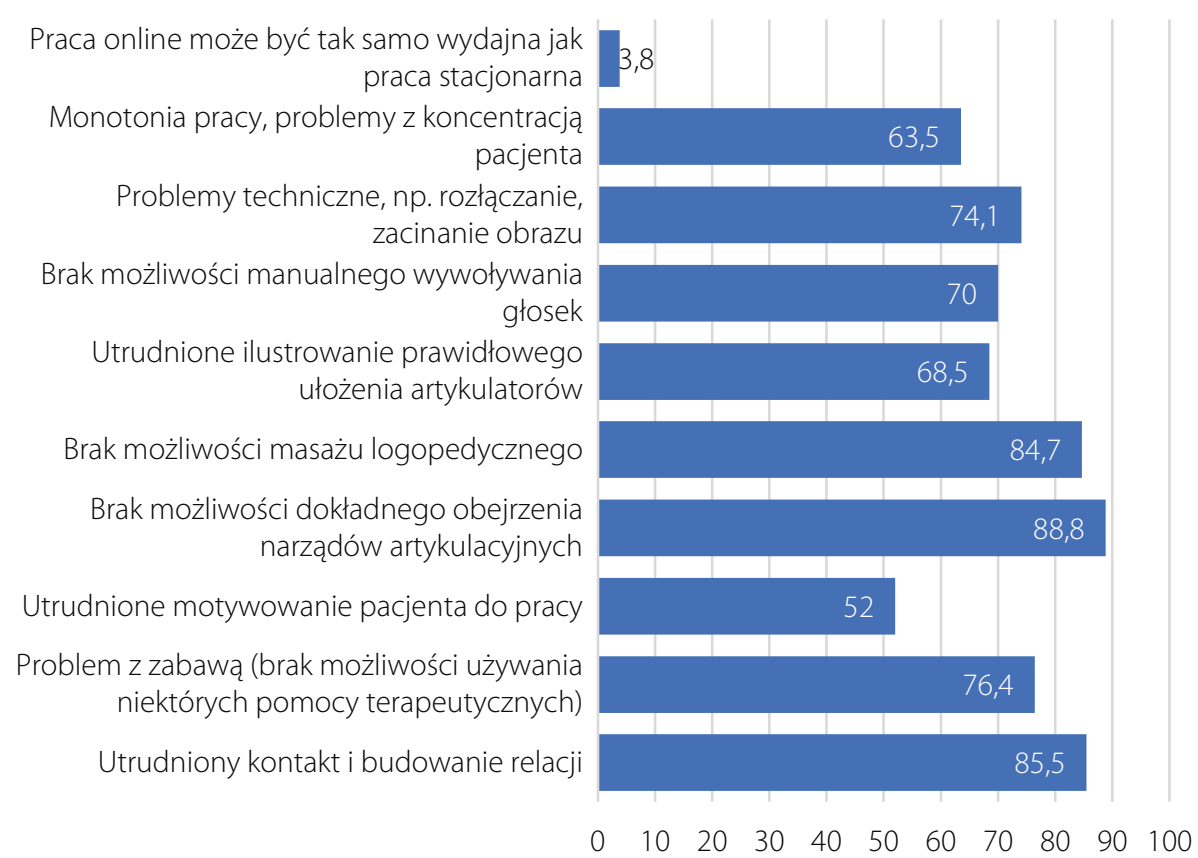

Rysunek 2. Wady terapii logopedycznej online z perspektywy logopedów

Źródło: opracowanie własne.

W świetle badania przeprowadzonego przez autorkę niniejszego tekstu pandemia wpłynęła nie tylko na zmianę sposobu pracy logopedów, lecz również na zmniejszenie liczby pacjentów (150 osób - 44\%), mniejszy komfort pracy (228 osób - 67\%), większe wydatki związane z ochroną przed wirusem, czyli kupno płynów do dezynfekcji, rękawiczek, przyłbic itp. (204 osoby - 60\%), stres i napięcie w pracy (163 osoby - 48\%), problemy finansowe (105 osób - 31\%). Tylko 7\% ankietowanych (24 osoby) nie odczuło żadnych negatywnych zmian. Wśród osób pracujących w prywatnych gabinetach większość narzekała na zwiększone wydatki (86 ze 120 osób, czyli 72\%). Z powyższych badań wynika więc, że okres pandemii wirusa COVID-19 był dla większości logopedów wyzwaniem na wielu płaszczyznach. Hipoteza mówiąca o niewystarczającym zabezpieczaniu się przed zarażeniem wirusem wywołującym COVID-19 została potwierdzona, gdyż logopedzi nie używają masek (3 osoby, czyli mniej niż 1\% logopedów, korzysta z masek z wysokim filtrem), a część z nich pracuje bez podstawowych środków ostrożności, takich jak dezynfekcja po każdym pacjencie 
(224 osób - 66\%), używanie przyłbicy (228 osób - 67\%) czy utrzymywanie dystansu społecznego (48 osób - 14\%). Specyfika zawodu sprawia, że logopedzi nie chcą pracować w pełnym zabezpieczeniu (maska połączona z przyłbicą), aby nie wywoływać strachu u dzieci i nie utrudniać im nauki właściwej artykulacji poprzez zasłanianie twarzy i prawidłowego ułożenia narządów artykulacyjnych.

\section{Analiza odpowiedzi z pytania otwartego}

W otwartym pytaniu dotyczącym refleksji badanych na temat pandemii COVID-19 i jej wpływu na funkcjonowanie logopedów pojawiło się wiele ciekawych wypowiedzi, których przytoczenie i omówienie stanowi rozwinięcie dotychczas przedstawionych wyników badania. Logopedzi zwrócili uwagę na to, że przyłbica czy maseczka nie tylko są niekomfortowe dla logopedy, ale również dla niektórych dzieci, zwłaszcza tych z głębszymi zaburzeniami, takimi jak choroby genetyczne, niepełnosprawność intelektualna czy autyzm. Nie pozwalają one przy tym na manualne torowanie głosek, używanie gestów komunikacji alternatywnej i dotykanie pacjenta. Ilustrują to między innymi następujące wypowiedzi:

- „Musi pokazać swoje usta, obserwować niezasłonięte usta podopiecznych, czasem przytrzymać, poprowadzić rękę, wykonywać masaże, plastrować itd." (kobieta, 42 lata, z miasta powyżej 200 tys. mieszkańców, pracująca w szkole);

- „Pracuję głównie z dziećmi ze spektrum. Nie mam możliwości pracy online. Moje dzieci źle reagują na wszelkie zmiany, nie mam możliwości pracy, zasłaniając twarz" (kobieta, 50 lat, z miasta poniżej 200 tys. mieszkańców, pracująca w prywatnym gabinecie w województwie śląskim; podczas obostrzeń zupełnie zrezygnowała z pracy i nie potrafiła wskazać, kiedy do niej wróci; w pytaniu o dodatkowe uwagi ankietowana zauważyła, że dzieci z autyzmem są nieprzewidywalne i często zdarzają się przypadki zachowań agresywnych, kiedy dziecko pluje, gryzie, bije terapeutę; za zasadną uznawała terapię online wyłącznie w przypadku dorosłych pacjentów bądź dzieci powyżej 9 lat, w normie intelektualnej);

- „W przypadku małych dzieci (placówka przedszkolna) lub osób z niepełnosprawnością intelektualną, autyzmem jest to trudne - często źle reagują na zabezpieczenia (maski, przyłbice), nie zachowują nawet minimalnego dystansu, ręce często w buzi, potem dotykają wszystkiego itp. W przypadku starszych dzieci czy osób dorosłych myślę, że jest możliwa bezpieczna stacjonarna praca" (kobieta, 50 lat, pracująca w przedszkolu specjalnym w województwie podkarpackim; w jednym z pytań podkreślała też, że nie stosuje zabezpieczeń, bo przy dzieciach ze specjalnymi potrzebami edukacyjnymi jest to niewykonalne);

- „Potrzeba bardzo dużo zabezpieczeń, żeby praca była bezpieczna, a tego moja poradnia nie zapewnia, np. ozonator. Mam do dyspozycji tylko przyłbicę, rękawiczki i środki do dezynfekcji. Prawie z niczego nie mogę korzystać z pomocy logopedycznych, bo nie nadają się do odkażania. A przy dzieciach 
z wyzwaniami zachowanie dystansu jest niemożliwe" (kobieta, 45 lat, pracująca w poradni psychologiczno-pedagogicznej w mieście do 200 tys. mieszkańców w województwie podlaskim; ankietowana zauważyła jednak, że dzięki pandemii pojawiło się wiele możliwości rozwijania własnych kwalifikacji przez większą ilość czasu oraz wysyp webinarów logopedycznych w internecie).

Jak wynika z wypowiedzi badanych, praca z dziećmi niesie duże ryzyko, gdyż dążą one do bliskiego kontaktu, nie dbają o zasady higieny i dość często nerwowo reagują na obecność maseczki czy przyłbicy, zwłaszcza jeżeli oprócz wad wymowy mają dodatkowe zaburzenia rozwojowe, takie jak autyzm czy niepełnosprawność intelektualna.

Dodatkowo logopedzi zauważają, że pandemia w dużej mierze zmieniła ich funkcjonowanie. Niektórym pozwoliła to zrozumieć wypełniana ankieta:

- „Nie zdawałam sobie sprawy ze zmian, jakie stopniowo pandemia wniosła w życie zawodowe. Dziękuję za zwrócenie uwagi” (kobieta, 37 lat, z miasta do 200 tys. mieszkańców w województwie małopolskim, pracująca w prywatnym gabinecie);

- „Boję się o przyszłość naszego zawodu oraz że nie potrafię prowadzić wydajnej i dobrej terapii logopedycznej online" (kobieta, 26 lat, z miasta powyżej 200 tys. mieszkańców w województwie mazowieckim, pracująca w przedszkolu);

- „Praca online i małe dziecko w domu, gdy nie ma się nikogo do pomocy, to bardzo trudne wyzwanie” (kobieta, 43 lata, ze wsi w województwie pomorskim, pracująca w prywatnym gabinecie);

- „Nie zauważam potrzeby ze strony rodziców, aby stosować obostrzenia podczas terapii z ich dziećmi, również nie otrzymałam takiego nakazu od obecnej szefowej. Pracuję »jak gdyby nigdy nic« :). Sama jedynie dbam o dezynfekcję rąk swoich i dzieci" (kobieta, 33 lata, z miasta powyżej 200 tys. mieszkańców w województwie mazowieckim, pracująca w prywatnym gabinecie; ankietowana zauważyła również, że bezpośrednia praca nie jest bezpieczna dla zdrowia logopedy, gdyż „[...] ciężko sterylizować zabawki po każdym dziecku, dzieci kichają, ślinią się, chcą się przytulać, ciężko zachować odpowiedni dystans. Dzieci muszą dokładnie widzieć i słyszeć, co do nich mówimy"; mimo świadomości zagrożenia nie używała jednak niemal żadnych środków ostrożności oprócz dezynfekcji dłoni);

- „Największe straty poniosły dzieci najmłodsze, z niepełnosprawnością. Regres, brak wsparcia i oddziaływań specjalistycznych. Rodzice nie są terapeutami, brak monitorowania efektów. Terapia logopedyczna online to fikcja" (kobieta, 45 lat, z miasta do 200 tys. mieszkańców w województwie zachodniopomorskim, pracująca w poradni psychologiczno-pedagogicznej; ankietowana zauważyła, że dla dzieci trudnością było odnalezienie się w nowej rzeczywistości: „Dzieci chcą kontaktu, potrzebują wskazówek, pomocy, tęsknią za tym, jak było”);

- „Ja nie wiem, co jest gorsze dla logopedy - praca online czy praca w maseczkach w zakładanej odległości” (kobieta, 29 lat, ze wsi w województwie pomorskim, 
pracująca w przedszkolu; ankietowana twierdziła przy tym, że „[...] zasady $2 \mathrm{~m}$ i w maseczce praca z dzieckiem są nielogiczne”);

- „Najważniejsza refleksja jest taka, że przed pandemią nie było łatwo o pracę, a teraz jest jeszcze gorzej i na pewno wielu logopedów musiało się przebranżowić, żeby przetrwać" (kobieta, 25 lat, z miasta powyżej 200 tys. mieszkańców w województwie łódzkim, pracująca w prywatnym gabinecie);

- „Byłam gotowa pracować online, nawet podsyłać dzieciom maile z zadaniami [...], ale rodzice nie chcieli podjąć współpracy w takiej formie” (kobieta, 32 lata, z miasta powyżej 200 tys. mieszkańców w województwie małopolskim, pracująca w prywatnym gabinecie logopedycznym).

Dzięki pytaniom otwartym odkryto, że niektórzy logopedzi zawdzięczają pandemii istotne zmiany, w tym również o charakterze pozytywnym:

- „Okres pandemii miał swoje plusy w postaci mnóstwa szkoleń online i webinarów. W wielu uczestniczyłam i podniosłam swoje kwalifikacje. Był czas na zaległe lektury specjalistyczne. Moja biblioteczka znacznie się powiększyła. Odkryłam wiele ciekawych grup logopedycznych i zakupiłam mnóstwo pomocy, bo był czas na szukanie" (kobieta, 50 lat, z miasta do 200 tys. mieszkańców w województwie podlaskim, pracująca w poradni psychologiczno-pedagogicznej);

- „Praca online miała swoje plusy, np. poznanie wirtualnych narzędzi do pracy, jednak wielu rodziców całkowicie odmówiło współpracy - niechęć do przebywania dzieci przed komputerem, trudności w zorganizowaniu zajęć online dla całej rodziny" (kobieta, 49 lat, z miasta powyżej 200 tys. mieszkańców w województwie mazowieckim, pracująca w przedszkolu);

- „Okres pandemii i konieczność pracy online bardzo wzbogacił mój warsztat pracy - m.in. korzystam z zasobów internetu, do których do tej pory nie sięgałam - będę je również wykorzystywać w pracy stacjonarnej. Ponadto przekonałam się, że praca online jest w niektórych przypadkach możliwa, a nawet skuteczna - dzieci były lepiej zmotywowane do pracy niż w czasie zajęć tradycyjnych (choć podejrzewam, że może to być efekt świeżości [...]. Ponadto po raz pierwszy od 18 lat pracy otrzymałam tak wiele pozytywnych informacji zwrotnych od rodziców, którzy zwykle nie uczestniczą w zajęciach z dziećmi, a w czasie zajęć online ich obecność była konieczna - po raz pierwszy mieli możliwość zobaczyć, ile wysiłku wymaga praca logopedyczna, skupienie uwagi dziecka, zaproponowanie ciekawych zajęć [...] mam nadzieję na powrót do placówek we wrześniu, m.in. ze względu na konieczność przeprowadzenia diagnozy, co bardzo byłoby trudne do zrobienia online" (kobieta, 42 lata, mieszkająca na wsi w województwie małopolskim, pracująca w szkole).

Internet staje się więc przestrzenią, która umożliwia rozwój (szkolenia, webinary, fora) i ułatwia znajdywanie ciekawych materiałów do wykorzystania podczas terapii logopedycznej [Kaptur, 2016, s. 110-122]. Pandemia COVID-19 była wyzwaniem dla logopedów i wprowadziła wiele zmian w sposobach ich pracy i funkcjonowania, ale 
pokazała również nowe możliwości terapii online i zweryfikowała ich skuteczność. Ankietowani wielokrotnie podkreślali trudności w pracy z osobami ze specjalnymi potrzebami edukacyjnymi, które nie tylko potrzebują bezpośredniego kontaktu, ale również trudno adaptują się do zmian.

\section{Wnioski i podsumowanie}

Logopedzi to grupa zawodowa szczególnie narażona na zarażenie wirusem SARS-CoV-2 wywołującym COVID-19 - z uwagi na specyfikę pracy. Większość zawodów ma możliwość $\mathrm{w}$ pełni zabezpieczyć się maską z wysokim filtrem, przyłbicą czy kombinezonem, a w logopedycznej pracy z dziećmi takie zabezpieczenie często oznacza ograniczone efekty terapii. Problem dotyczy również tych dzieci, dla których zmiany są trudne lub przerażające, na przykład dzieci z autyzmem, niepełnosprawnością intelektualną bądź dzieci do 3. roku życia, które są przyzwyczajone do bliskości z terapeutą.

Pandemia wymusiła zmiany w funkcjonowaniu logopedów, takie jak częstsza dezynfekcja powierzchni, przerwy między umówionymi pacjentami, rezygnacja z niektórych zabawek i pomocy niemożliwych do zdezynfekowania, budowanie dystansu z pacjentem, częstsze stosowanie rękawiczek, przyłbicy i maseczek, a także prowadzenie zajęć online, co do tej pory wydawało się niemożliwe. Zmiana sposobu pracy spowodowała zmniejszenie liczby pacjentów, przy jednoczesnym zwiększeniu wydatków na różnego rodzaju zabezpieczenia przed rozprzestrzenianiem się wirusa.

W terapii logopedycznej konieczne jest kontrolowanie ułożenia narządów artykulacyjnych, sprawdzanie budowy aparatu artykulacyjnego i jego sprawności, a czasem manualna pomoc $\mathrm{w}$ wywołaniu głoski $\mathrm{z}$ wykorzystaniem narzędzi bądź ręki zabezpieczonej rękawiczką. Aby nauczyć pacjenta danego ćwiczenia, terapeuta powinien je zaprezentować na sobie, co nie jest możliwe w masce i wymaga zmniejszenia dystansu. Z badań wynika, że logopedzi stosują zabezpieczenia wybiórczo i najczęściej rezygnują z noszenia maseczki. Argumentują to mniejszą skutecznością pracy w masce i niechęcią dzieci do zmian. Większość uczestników badania uznała pracę online za mało wydajną i w niektórych przypadkach całkowicie niewskazaną czy wręcz niemożliwą, choć niektórzy z nich byli do niej zobligowani, na przykład pracując w szkołach, które w pełni przeszły na nauczanie zdalne. Terapia online jest przez logopedów postrzegana jako ostateczność, gdyż utrudnia nie tylko dokładną diagnozę (np. ocenę wędzidełka języka), ale również ogranicza możliwość budowania relacji z pacjentem i jest przepełniona problemami technicznymi, a także licznymi przeszkodami - na przykład w postaci hałasu w domu.

Logopedzi twierdzili (335 osób - 98,5\%), że ich praca jest najbardziej wydajna wtedy, kiedy mogą pracować bezpośrednio, mieć kontakt z pacjentem, pokazywać prawidłowe ułożenie narządów artykulacyjnych, co w tym czasie było niemożliwe. Pandemia wirusa COVID-19 wpłynęła na wykonywanie zawodu logopedy przede 
wszystkim negatywnie, ale też nauczyła tych specjalistów korzystania z nowoczesnych technologii i (z uwagi na zmniejszoną liczbę pacjentów bądź zupełne zamknięcie gabinetów, szkół i przedszkoli) dała czas na samodoskonalenie.

\section{Literatura}

Aggarwal K., Patel R., Ravi R., 2020, Uptake of telepractice among speech-language therapists following COVID-19 pandemic in India. Speech, „Language and Hearing”, https://doi.org/10.10 80/2050571X.2020.1812034

Cieszyńska-Rożek J., Korendo M., 2015, Wczesna interwencja terapeutyczna. Stymulacja rozwoju dziecka od narodzin do 6. roku życia, Kraków: Wydawnictwo Edukacyjne.

Emanuel E.J., Persad G., Upshur R., Thome B., Parker M., Glickman A., Zhang C., Boyle C., Smith M., Phillips J.P., 2020, Fair Allocation of Scarce Medical Resources in the Time of COVID-19, „The New England Journal of Medicine”, no. 382, s. 2049-2055, https://doi.org/10 $.1056 /$ nejmsb2005114

Fong R., Fung Tsai C., Yan Yiu O., 2021, The Implementation of Telepractice in Speech Language Pathology in Hong Kong During the COVID-19 Pandemic, „Telemedicine and e-Health”, vol. 21, no. 1 , s. 30-38.

Grabias S., 2010, Logopedia - nauka o biologicznych uwarunkowaniach języka i zachowaniach językowych, „Logopedia”, nr 39/40, s. 9-34.

Jatkowska J., 2020, Nowe technologie w terapii logopedycznej dzieci z zaburzeniami mowy, „Logopaedica Lodziensia”, nr 4, s. 73-84.

Kaczorowska-Bray K., Zielińska-Burek M., 2012, Zaburzenia rozwoju psychoruchowego wplywające na rozwój mowy i języka dziecka, [w:] I. Nowakowska-Kempna (red.), Studia z logopedii i neurologopedii, Kraków: Wojskowa Akademia Medyczna, s. 55-94.

Kaptur E., 2016, Logoped(i)a online, czyli o internetowym rynku ustug logopedycznych, [w:] A. Momot (red.), Media XXI wieku - studia interdyscyplinarne, Wrocław: Stowarzyszenie Młodych Twórców „Kontrast”, s. 110-122.

Kapusta P., 2020, Pandemia - raport $z$ frontu, Kraków: Wydawnictwo Insignis Media.

Koronawirus ma związek z przypadkami bruksizmu?, 2020, https://dentonet.pl/koronawirus-ma-zw iazek-z-bruksizmem/\#gref (dostęp: 2.11.2020).

Kozinets R.V., 2012, Netnografia. Badania etnograficzne online, Warszawa: Wydawnictwo Naukowe PWN.

Landsverk G., 2020, Face shields did not protect people from the coronavirus in an outbreak in Switzerland, but masks did, health officials say, https://www.insider.com/face-shields-did-not -protect-people-from-coronavirus-swiss-outbreak-2020-7 (dostęp: 2.11.2020).

Pluta-Wojciechowska D., 2020, Logopedia jako nauka interdyscyplinarna w oczach logopedów. Wstępne wyniki badań, „Logopaedica Lodziensia”, nr 4, s. 141-155.

Sambor B., 2015, Zaburzone wzorce połykania i pozycji spoczynkowej języka a budowa artykulacyjna głoskowych realizacji fonemów u osób dorostych, „Logopedia”, nr 43/44, s. 149-188.

Vecerkova E., 2020, Logopedické terapie online, Hradec Králové: Bakalářská prace, Pedagogická fakulta Univerzity Hradec Králové.

Verma S., Dhanak M., Frankenfield J., 2020, Visualizing droplet dispersal for face shields and masks with exhalation valves, „Physics of Fluids” vol. 32(9), https://aip.scitation.org/doi/10.1063/5.002 2968 (dostęp: 2.11.2020). 


\begin{tabular}{|l|l|}
\hline \multirow{2}{*}{ Co Creative } & $\begin{array}{l}\text { ○ by the author, licensee tódź University - Łódź University Press, tódź, Poland. } \\
\text { This article is an open access article distributed under the terms and conditions } \\
\text { of the Creative Commons Attribution license CC-BY-NC-ND 4.0 } \\
\text { (https://creativecommons.org/licenses/by-nc-nd/4.0/) }\end{array}$ \\
\cline { 2 - 2 } & Data złożenia: 11.08.2021. Data przyjęcia: 11.10.2021. \\
\hline
\end{tabular}

